\title{
Origins of child rights governance: The example of early child labour legislation in the United States and Brazil
}

2019, Vol. 26(3) 289-303

(C) The Author(s) 2019

Article reuse guidelines: sagepub.com/journals-permissions DOI: |0.1 |77/090756821985024| journals.sagepub.com/home/chd

@SAGE

\section{Nina Schneider}

Käte Hamburger Kolleg/Centre for Global Cooperation Research, University of Duisburg-Essen, Germany

\begin{abstract}
Adopting a historical and comparative perspective and moving beyond the North-South divide in the historical literature on child rights governance, this article contrasts the first enduring national anti-child labour laws in the United States and Brazil - the US Fair Labor Standards Act of 1938 and the Brazilian Minor's Code (Código de Menores) of 1927. It identifies key political structures that conditioned these laws, and examines how these influenced the timing, scope, clustering, and impact of early child rights legislation.
\end{abstract}

\section{Keywords}

Brazil, child labour history, enforcement, first child labour laws, Global North, Global South, origins of child rights governance, United States

While contemporary child rights governance has been studied, detailed knowledge of the origins and early rationale for child rights regulations is scarce, especially across the socalled 'Global South'. ${ }^{1}$ This applies, in particular, to child labour regulations - an important aspect of child rights governance. Much of the existing historical literature adopts national perspectives, focusing particularly on Britain, the United States, and other regions of the so-called 'Global North' or 'West'; see the International Labour Organization's bibliography (ILO; 2002: IX, 25-27). ${ }^{2}$ Detailed comparative histories of early childhood governance are similarly rare, and most studies are limited to the West (Cunningham, 2005 [1995]; Heywood, 2017), with Stearns' (2016) study being one of the few exceptions. Cunningham (2005 [1995]: iix-ix) argues that future scholarship

\section{Corresponding author:}

Nina Schneider, Käte Hamburger Kolleg/Centre for Global Cooperation Research, Universität Duisburg-

Essen, Schifferstraße 44, 47059 Duisburg, Germany.

Email: nina.schneider@uni-due.de 
should investigate the extent to which Western history of childhood and children - of which child rights governance forms part - is particular.

This article seeks to contribute to our knowledge on child rights governance in a twofold way: by adopting a historical and comparative perspective and by moving beyond the dominant North-South divide in the literature. Revisiting the origins and impact of child rights governance in the form of child labour legislation, it analyses how and why diverse systems of child labour governance emerged in different parts of the world - specifically the United States and Brazil. ${ }^{3}$ Child labour (or factory) laws form a fruitful subject for the study of early child rights governance. Discussions about child labour were intrinsically linked to a broader set of child rights including the right to health, education, play and good family life. In a complex and protracted process, the ideal of the working child gave way to the notion of the precious child with a right to childhood, school and play, who should be protected from exploitation (Schmidt, 2010; Zelizer, 1985). These broader discussions about child rights were instrumental to, and an integral part of, debates about child labour legislation.

Yet, the shift in conceptualising the child, the timing of child rights governance and its form varied between countries. Certain child rights were granted earlier and in turn affected the timing of other rights (e.g. schooling and child labour; Sandin, 2014). In some places, child labour laws impacted positively on child education governance or vice versa, while in others, legislators merely tried to accommodate work and schooling. The clustering of different child rights was significant. Different types of federalist and legal traditions, too, offer an important explanation for divergences in child rights governance. In the United States, authority over specific kinds of child rights governance like compulsory schooling lay with the state rather than the federal government.

This article analyses how and why early child rights governance diverged, taking child labour regulation as a poignant example. It pursues three aims: (1) to identify key institutional and political structures that conditioned and hindered early child rights laws, (2) to examine how these structures influenced the scope and timing of the respective legislation and (3) to investigate the impact of the laws. It contrasts, the first major anti-child labour laws in the United States and Brazil - the US Fair Labor Standards Act (FLSA) of 1938 and the Brazilian Minor's Code (Código de Menores) of 1927 - which formed the basis for enduring national child labour governance in both countries. Research questions include the following: Why were the laws passed at a specific moment in time? Which actors or institutions promoted or hindered them and how? What scope did the laws have, and were they politically progressive and audacious, or timid and toothless? Importantly, were they effectively enforced?

The research design involves a historical and comparative approach. It frames the comparison around three aspects which varied considerably in the two cases: (1) institutional and political arrangements including the federal structure and legal tradition, (2) the timing and (3) the scope of the law. It traces and juxtaposes the processes, including the factors that first inhibited and eventually enabled initial child rights and child labour laws. Comparisons between nations pose several challenges. The perspectives and categories of comparison are artificially selected and incorrectly regarded as stable, and comparisons may silence processes of cultural entanglement (Werner and Zimmermann, 2002: 610-612). This article adopts a comparative approach for three reasons. Moving beyond the national literature allows us to explore similarities and differences across the 
North-South divide, identify additional key characteristics of national histories of child rights governance and comprehend the emergence of child rights governance from a truly global perspective - the aim of this special issue.

Brazil and the United States seem particularly suitable for comparison given their comparable size, shared histories of colonialism, slavery and European mass migration. Moreover, Brazilian advocates for the protection of child labourers studied overseas legislation and - importantly and somewhat ironically - took industrialised countries such as the United States as role models. Thus, in this article, I offer some initial observations about key similarities and differences between Brazil and the United States in order to identify important explanatory factors in the history of child rights governance that are obscured by national analyses. I concentrate mainly on the lesser-known Brazilian example, while the history of US child rights governance serves as a foil for comparison.

While primary sources on the United States include reformers' publications, the autobiography and edited letters of Florence Kelley, and child labour law texts, Brazilian primary sources include publications by medical doctors, lawyers and politicians; annual reports of the State of São Paulo; Congress and Senate files; press articles; child congress proceedings; and monthly reports from the regional ILO delegate to Brazil.

I argue that different types of federalist constitution, along with particular judicial traditions, conditioned and constrained systems of child rights governance in both countries and help explain the incongruence in timing, scope and effect of early child rights legislation such as child labour laws. In the case of the US federal system, child rights legislation was traditionally decided and implemented at state level. The battle for authority over child rights governance between the state and federal government explains why, in the United States, federal child labour legislation was late (1938), limited in scope and comprised only a subsection of a law regulating adult labour. In Brazil, by contrast, where early state-level child labour legislation was absent or ineffective, federal child labour legislation came earlier (1927), as political and juridical resistance to the federal law was significantly less than in the United States and, importantly, formed part of an extensive package of child rights. While conventional wisdom holds that the more widely studied states of the Global North were more advanced in child rights governance, this article argues for more nuanced and even contrary assessments.

As the United States has received more attention, I discuss the history of US child rights legislation concisely, using it to provide background and guidance for analysis. I begin by tracing the run-up to the US FLSA of 1938, its scope and impact, and then discuss the process that led to the Brazilian Minor's Code of 1927 including the actors involved, previous legislative efforts, and the scope and impact of the law. Importantly, Brazilian contemporary sources refer to the 'minor' (menor) instead of the 'child'. Widely used in several Latin American countries, the term 'minor' was pejorative, denoting children associated with poverty and crime, or at risk of becoming pauper delinquents (Kuznesof, 2009: 318).

\section{Child labour in US history and its opponents}

Child labour had been common in the United States from colonial times for large parts of the poor population. Cultural historians have often stressed the legacy of a widespread belief that people were responsible for their own poverty, possibly rooted in the English 
poor laws. According to Puritan thought, hard work was the ideal, and child labour was justified as preparing children for future working life (Pieris, 2004: 188; Hobbs, McKechnie, and Lavalette, 1999; Zinn, 1995). Industrialisation increased child labour in the United States, beginning in the early 19 th century and spreading unevenly across different states (Hindman, 2002: 7, 12-44). The Southern states industrialised later and most fervently resisted child labour legislation. Like in Brazil, European mass migration played a key role in the history of child labour. Most migrant families viewed child labour as normal and necessary, and sweatshop labour in the garment industry was a common source of income for household economies (Stearns, 2009: 42). New migrants were forced to sign exploitative bondage contracts, and employers preferred children as a cheap and obedient labour force (Zinn, 1995: 189). US child labour peaked in 1910, when $18 \%$ of the total child population ( 2 million) were employed, excluding widespread farm labour. By 1920, the number of working children under the age of 15 years had declined to 8\% (Stearns, 2009: 42).

The main institutional and political obstacles to early child rights legislation in the United States have been well-documented, especially the peculiar nature of American federalism. Because of the constitutional Tenth Amendment, legislation, including employment and schooling regulations, was subject to state sovereignty rather than the federal government. Earlier efforts to ban child labour took place at state level, leading to what Hindman (2009: 482) pointedly called a 'patchwork' of child labour legislation. Schooling, too, was subject to state-level authority, while legislation likewise differed greatly between individual states. Regarding child labour, both employment specifications (minimum age, working hours and hazardous employment) and the actual enforcement of state child labour laws varied. A good example is the 1893 progressive child labour law of Illinois, authored by the leading reformer Florence Kelley (1859-1932), which introduced provisions for an inspection system. Kelley was appointed the first female Chief Factory inspector, yet her work was often sabotaged even by public officials (Kelley, 1986: 83, 86). In August 1897, Kelley was dismissed when a less reformoriented governor took office who maintained cordial links with the Illinois Manufacturers' Association (Sklar, 1995: 286).

Florence Kelley (1905: 103) was a key advocate for federal child labour legislation because she believed the patchy state-level laws prompted a 'race to the bottom', whereby more lenient legislation in one state made more stringent labour standards in other states irrelevant. The more industrialised states (e.g. New York State, Pennsylvania) typically pioneered more progressive child labour laws. By 1900, all industrialised Northern states had reduced children's working hours in mining and manufacturing, while the Southern states were latecomers to child labour legislation. Nonetheless, legislation in all states offered exemptions for children to work in family businesses, and inspection was often lacking.

In 1904, Florence Kelley became a founding member of the National Child Labor Committee (NCLC), which marked the emergence of a national anti-child labour movement. The NCLC began to shape public opinion and exert pressure for stricter state, followed by federal, legislation (Trattner, 1970). Initially, efforts to implement federal child labour legislation were unsuccessful. Legal initiatives proposing a minimum working age and limiting working hours either failed (the Beveridge Bill of 1906) or were 
passed and subsequently declared unconstitutional (e.g. the Keating-Owen Bill of 1916 banning interstate trade in products produced by child labour or the Child Labour Tax Act of 1918; Felt, 1970: 469-475; Hindman, 2009: 484-485). These cases demonstrate how the US federalist system and specific legal tradition formulated, impeded and delayed federal child labour legislation. Even if federal laws were successfully ratified by Congress, they were often challenged in court and overturned by the Supreme Court.

\section{Advent and scope of the US FLSA of 1938}

The division of authority between the state and federal level over governing different kinds of child rights helps explain why a federal child labour law was so long delayed. Regulating various child rights at two different levels may have created conflicts. For example, discrepancies could emerge between state-level schooling and federal-level child labour legislation. Schooling legislation was implemented at state level. If a federal child labour law determined a minimum age that conflicted with a state-level compulsory schooling law - because compulsory schooling ended at a younger age than the federal minimum age- it would have resulted in a gap and created a problem for state legislators. This shows how child labour was intrinsically linked to other child rights and how disparities in legislative authority over specific child rights complicated child rights governance as a whole.

The first lasting federal law to regulate child labour - the FLSA - was only passed in 1938, applied solely to non-agricultural employment and was essentially an adult labour law with a few references to child labour rather than a proper child rights law. It regulated wages and working hours in general and comprised several provisions for child workers including a general minimum age of 16 years with specific regulations for children younger than 16 years. Children aged 14 and 15 years, for example, could work after school in selected jobs, with hours restricted to 3 hours on school days, 18 hours during the school week, and 8 hours on non-school days, respectively (U.S. Department of Labor [DOL], 2011 [1938] 4-5 (Sec. 203[1]), 29-40 (§212-13); Pieris, 2004: 192-193).

However, scholars have questioned the FLSA's effectiveness on several grounds. Felt (1970: 469-475) emphasises two main weaknesses: the law only codified the status quo and its minimal scope had negligible effect on curbing child labour. Overall, the FLSA regulated only those sectors where child labour was in decline. Drawing substantially on the failed Keating-Owen Bill of 1916, the only novelty of the FLSA was to raise the minimum age for factory work from 14 to 16 years, a standard already being met in eleven states, covering $40 \%$ of the population. ${ }^{4}$ The FLSA only regulated industrial labour, neglecting agriculture and street trades in which approximately $94 \%$ of children worked. It thus affected a mere $6 \%$ of the total contemporary child labour force under 16 years of age (Felt, 1970: 478). Only in 1974 was an amendment passed to set a minimum age of 14 years in agriculture, and even this could be lowered to 12 years if accompanied by a parent or with parental agreement (Hindman, 2006, 2009: 485).

Overall, the impact of the comparatively late, selective and lenient FLSA on the decline of child labour was comparatively small. In the United States, local court rooms seem to have played an instrumental role in the re-evaluation of child labour and its eventual demise. In his study of the Appalachian South - although he relates his findings 
to the entire nation - James Schmidt (2010) argues that court proceedings involving accidents suffered by child workers played a key role in the shift towards a new cultural conception of child labour. Child labour was increasingly regarded as undesirable by judges, and working-class parents and child workers adopted the legal child labour language to win their cases. While other scholars have credited a combination of factors for the demise of US child labour - state-level child labour and compulsory schooling laws, reformers' campaigns and public pressure, parental decision-making that increasingly favoured education, and technological advances (Hindman, 2009: 484; Trattner, 1970: 10-11; Zelizer, 1985: 62-63; Stearns, 2009: 42) - Schmidt argues that the increasing tendency among judges to fine manufacturers, and working families to sue child employers for negligence, meant that manufacturers were eventually forced to obey the law and hence child labour became less profitable (Schmidt, 2010: 166, 175, 191). His study illustrates how the US legal tradition is characterised by the common law system in which local and state-level courts play an instrumental role. The US Supreme Court upheld that tradition by blocking early child rights legislation at federal level. In sum, the United States' unique common law tradition and federalist constitution significantly constrained early child rights governance at federal level.

\section{Child rights in Brazilian history and its opponents}

In Brazil, child rights governance developed in a very different manner. Since the 1890 s, an alliance of medical doctors, lawyers and journalists had increasingly pressured legislators to pass national child assistance laws and delegate child governance to the state rather than private charities and religious institutions. Domestic and international factors contributed to the Minor's Code. The former included the elevation of the child to a symbol of the nation's future in the newly installed Republic (1889), a time when nationbuilding was the main project of a generation of intellectuals (de Carvalho, 1991). Demographic factors included the high population growth and infant mortality in Brazil which outnumbered that of its Latin American neighbours (Luna and Klein, 2014: 5-6); the much greater number of illegitimate children in Latin America than in Europe or the United States, ranging from $30 \%$ to $50 \%$ depending on time and community (Milanich, 2002: 73, 74); and the high rates of child delinquency and abandonment, respectively, which prompted an urgent need to maintain social order by governing pauper children (Rizzini, 2011 [2007]: 24). ${ }^{5}$

In the absence of a nationwide civil-society organisation like the NCLC in the United States, a loose national alliance was formed which included individuals and professional groups championing different but overlapping child rights; medical doctors (hygienists) aimed to curb infant mortality, while lawyers cooperated with the police to demand separate prisons for children and the building of asylums, and criminal laws adapted for children (Rizzini and Pilotti, 2011: 22-23). Together they increased the pressure on legislators to strengthen child rights first in the municipality and federal capital of Rio, and then progressively extending to the federal Congress and the entire nation. Attitudes towards children were influenced by ideologies as diverse as positivism, eugenics, higienismo and international criminal anthropology, which, although widespread throughout Latin America (Guy, 2002: 140), blended into a peculiar practice of 
post-abolition Brazilian racism that closely connected race with class (Kassouf and Santos, 2011; Rizzini, 2011 (2007): 421, 433; Dourado and Hecht, 2004: 114-116).

The domestic alliance for state-led child rights regulation was both inspired and supported by key thinkers, scientists and politicians from abroad, especially through international conferences relating to children's health and child-specific justice. Brazilians participated in international child congresses and frequently argued that Brazil needed to keep up with other nations' progress. Many were inspired by landmark events in global child governance like the first American Child Congress in Buenos Aires in 1916 and the 1919 Washington Conference which passed the ILO's minimum age convention. While the child health movement was strongly influenced by France (Moncorvo Filho, 1926: 108-109, 168), the justice movement was inspired by the United States and Scandinavian countries - Chicago's juvenile courts from 1899 and Scandinavian Child Welfare Boards for the protection of children from 1896 onwards, Norway taking the lead (De Moraes, 1916: 59-61; Rizzini, 2009: 111). Brazilian protagonists were both galvanised by and formed part of these larger international child rights movements.

These actors published extensively on the problem of infant mortality, child labour and health, and delinquency and produced the first official statistics. As in the United States, these statistics both provided evidence and brought the child labour problem to wider public attention. Moncorvo Filho developed the first health statistics to record the mortality rates and published annual statistical reports from 1901 onwards (Moncorvo Filho, 1926: 135-136, 153). In 1902, he co-founded the Scientific Society of Child Protection (Moncorvo Filho, 1926: 151-152). Similarly, Ataulpho de Paiva attended international congresses and produced the first reliable statistics about existing public and private assistance to children in Rio (Rizzini, 2009: 110-112). As in other countries, Brazilian actors combined their public policy efforts with the development of their respective disciplines. Thus, in Brazil, the call for child labour regulation formed one strand out of a bundle of interrelated child rights.

The key child governance actors were upper-class and middle-class Republicans eager to build a new Brazilian nation on a par with what they regarded as 'civilised' or 'cultured' nations. Such terms were frequently used to describe the industrialised nations of Europe and the United States, which were seen as role models by Brazil's nationbuilding elites (Mello Mattos, 1929: iii, vi). To achieve parity with these other nations, it was necessary to curb infant mortality, child delinquency and child exploitation. The Republican movement failed to expand political and civil rights and often even curtailed them (for example, the illiterate population was denied voting rights and received no formal education). José Murilo de Carvalho (1991: 45) characterises the Republican State as paternalist: political rights did not form part of the notion of citizenship at the time; rights were not to be won by the citizens but granted by the paternalistic ruling elites. While the Brazilian labour movement had called for child labour to be curbed, it was suppressed and declined by the late 1920s (Luigi, 2011). Conceivably, the Brazilian Minor's Code - essentially a top-down law - reflects this paternalism. In the United States, by contrast, numerous philanthropic organisations like the NCLC along with the labour movement (Trattner, 1970: 33) mobilised against child labour, and social justice feminists (Sklar et al., 1998: 4-7) like Kelley played leading roles in the struggle. In 
Brazil, the anti-child labour alliance was primarily driven by wealthy protagonists and lacked both female leaders and organised support from civil society. ${ }^{6}$

\section{Child labour in Brazil and previous efforts to regulate it}

Child labour in Brazil, too, has a long and varied past, and depended on the child's racial and ethnic origin, class, migrant/native status and gender (Kassouf and Dos Santos, 2011: 418, 420; Dourado and Hecht, 2004: 114-115, 117; Kuznesof, 2009: 319). By contrast with Europe and the United States, child labour in Brazil increased at the turn of the 20th century; a period marked by the abolition of slavery in 1888 and the peak of European mass immigration. While, in 1890, children formed about $15 \%$ of São Paulo state's industrial labour force, with nearly $25 \%$ employed in the textile sector, by 1919 , children constituted $37 \%$ of all textile workers in the state and $40 \%$ of workers in the city as a whole (Kassouf and Dos Santos, 2011: 418, 420; Arquivo Estadual de São Paulo (AESP), 1894).

The first legal measure to control child labour was passed at municipal level in Brazil. In 1891, a conservative Factory Act was introduced, but restricted to the city of Rio de Janeiro. Explicit and implicit evidence shows that the 1891 Rio child labour Factory Act was not enforced. As late as 1919, Rui Barbosa (1919: 387), Brazilian politician and writer, condemned the persistence of child labour in the capital's factories: 'this law was not enacted until today. [...] it was not executed, as if it had never existed'. ${ }^{7}$ There is abundant proof of the persistence of child labour. Examining the widely-read Journal do Commercio, Aline Soares (2017: 112) discovered 1,223 job advertisements for children during the period between 1888 and 1927. Companhia América Fabril, a major textile company in Rio, employed children aged between 5 and 14 years until 1920 (Araujo, 1993: 163). The child labour situation and debate in the federal capital of Rio was hugely significant for the country as a whole because Rio was Brazil's political and intellectual centre. Provisions from the Rio Factory Act were later integrated into the Minor's Code and extended to federal level.

The first senator to put child assistance on the national agenda was Lopes Trovão, a medical doctor often credited as one of the pioneers of child rights (Moncorvo Filho, 1926: 133; Rizzini, 2009: 117). In his speech of 11 September 1896, Trovão first described the misery of the many abandoned children who were forced to sleep on the streets where they became accustomed to 'all kinds of crime' (Moncorvo Filho, 1926: 130-131). Trovão went on to emphasise children's key role for the future of the nation: 'We have to construct a Patria (fatherland), build a nation, and make a people [...] what element is more mouldable than children?!' (Moncorvo Filho, 1926: 133).

In 1906, the deputy Alcindo Guanabara demanded a law to create institutions specifically for abandoned and delinquent children that would separate them from adults, but this project was discarded due to a lack of financial resources (Bandera, 2014; Brasil). In 1912, the deputy João Chaves advocated that the State should have greater powers of intervention in the case of children and demanded the creation of child-specific tribunals - which later became the Minor's judicial system. This law also failed due to a lack of funds (Bandera, 2014: 748; Code of 1929). Finally, in 1917, the deputy Alcindo Guanabara proposed a third law containing both the demands of the 1906 (child-focused institutions) and 1912 laws (juvenile courts), but it was aborted due to Guanabara's death 
(Bandera, 2014: 748; Guanabara, 1917). Nonetheless, similarly to the US case, all three laws served as a basis for subsequent laws. In 1917, however, a deputy from Rio succeeded in passing stricter municipal child labour provisions in the capital, but the municipal law faced stiff resistance from dozens of carioca businessmen and the Brazilian Industrial Centre (Centro Industrial do Brasil, CIB). Eventually, these industrialists managed to overthrow the law in the second instance at the Supreme Court (Alvim, 1985: 45-50; Braga, 1993). Thus, in 1917, a stricter municipal child labour law in Rio was barred by the Supreme Court who ultimately supported industrialists' interests.

\section{Advent and scope of the Brazilian Minor's Code (1927)}

The Minor's Code project gained momentum throughout the 1920s. In 1922, the first Brazilian Child Congress was held which resulted in a catalogue of demands for child rights governance (Moncorvo, 1926). The Brazilian Bar Association (BBA) also convened in 1922 and delegates demanded legislation to regulate child labour. The lawyers took an important decision: the general right of individual states to pass penal legislation, as granted by the Republican federalist system, did not prohibit a federal law for child protection uniformly applied to the entire nation (Braga, 1993: 100-101). The BBA delegates thus decided that a federal child labour law could not be jeopardised by single states and thereby strengthened the power of the federal Congress.

In addition, the renowned laywer Mello Mattos (1864-1934) was officially tasked with developing child rights legislation. In December 1923, he succeeded in passing a decree that reorganised the Justice sector in the federal capital of Rio and created the post of the Minor's Court Judge (juiz de menores). Mello Mattos himself was appointed and thus became the first Minor's Court Judge of Latin America. In February and April 1924, he passed two decrees, also restricted to the federal capital, regulating public assistance and housing for pauper children (Bandera, 2014: 748; Rizzini, 2009: 130). From 1925 onwards, Mattos' law project for the Minor's Code was proposed to and discussed by the Senate, revised and significantly extended, and finally ratified in 1927 (Bandera, 2014: 748; Rizzini, 2009: 132).

While it is beyond the scope of this article to discuss parliamentary debates in detail, the general question of workers' rights had gained prominence since the massive strikes in São Paulo in 1917. Angela Gomes (1979) distinguishes three main groups in this debate: the São Paulo (paulista), Rio Grande do Sul (gaúcha) and Rio factions. The Paulistas favoured social legislation to demobilise the workers' movements; the Gaúchos objected to any kind of state regulation of labour and only accepted medical arguments like curbing infant mortality and preserving the Brazilian 'race'; while the pro-labour deputies of the Rio group (trabalhistas) championed more progressive social legislation with greater child labour restrictions including shorter working hours and a minimum working age of 14 years (Braga, 1993: 44-46, 59). While some deputies, medical doctors and workers argued that labour jeopardised children's health and the future of the nation, businessmen, especially from the textile sector, dismissed claims about children's physical fragility and justified child labour as beneficial in teaching children a trade and avoiding child vagrancy and delinquency (Alvim, 1985; Braga, 1993: 71, 74). 
The Minor's Code that was eventually passed (Decree No. 17.943 A from 12 October 1927; Presidência da República, 1927) was not primarily a child labour but a wideranging child rights law. Comprised of 231 articles, it was designed to ensure comprehensive legal provision for a myriad of conflict situations involving children under the age of 18 years. The Code covers diverse issues such as child delinquency, abandoned children and the duties of the Minor's judge, while only one chapter - Chapter IX - regulates child labour.

Chapter IX set the overall minimum age for child workers throughout Brazil at 12 years (Chap. 1, Art. 101), yet child labour between 12 and 14 years was conditional, and most children could not fulfil the requirements. ${ }^{8}$ Children younger than 14 years who had not yet finished primary school - the majority at that time - were banned from working, with exemptions for those who needed to work for their subsistence or family businesses. Working hours for child workers, including apprentices under the age of 18 years, was limited to six per day with obligatory breaks totalling at least 1 hour. All workers under 18 years were obliged to show a medical certificate that was provided free of charge. In sum, depending on their individual situation, children were allowed to work from age of 12 or 14 years onwards, with only specific kinds of work such as nightshifts and hazardous work (allowed for those over 18 years of age) prohibited. If the law was violated, fines (or even prison terms) were applied to both the employer and child's parent or legal guardian.

The Minor's Code marked a shift from previously private and decentralised assistance to children through charity, sporadically supported by official funding, to a systematic and comprehensive child rights policy codified in law that declared the state ultimately responsible for the well-being of its young population. Many legal texts commenting on the Minor's Code still justify the urgent necessity of state intervention, which highlights a long history of resistance to such policies. A typical example appears in Mello Mattos' preface to a book on the Minor's Code authored by his assistant, Beatriz Mineiro (1929). Mattos argues that it is the state's most urgent duty to care for the well-being of children, as proper child governance served as a means 'to protect (the state)' and the nation's very future (Mello Mattos, 1929: 3-4). He explicitly justifies state intervention not merely as an act of 'human solidarity' but as necessary for the 'conservation of the social order' (Mello Mattos, 1929: 3-4). A critical perspective reveals that Brazilian legislators generally took an ambivalent view of the child. Children represented the nation's future and hope and were thus deserving of assistance and protection, but they also posed a risk to the nation's future and, in this respect, required paternalistic 'rehabilitation' (Rizzini, 2011 [2007]: 25, 50) and social control (Kuznesof, 2009: 318).

\section{Impact and revision of the Code's child labour regulations}

How were the child labour restrictions received, and were they applied? Rizzini (2009: $136,138)$ claims that the law did not encounter major resistance. However, documents from the ILO Archives in Geneva, studies by Braga (1993: 137-156) and Alvim (1985), and press articles from the time prove otherwise. The Code's child labour provisions faced massive opposition from business associations in Rio and São Paulo. 
While Mello Mattos tried to defend and enforce the 1927 child labour provisions, he was eventually forced to dilute the regulations for child labour in factories. Manufacturers' opposition to child labour restrictions was closely tied to their resistance to any federal interference in labour relations.

In the monthly reports of June 1929 and February 1930, the Brazilian ILO representative in Rio, M. de Souza, describes the systematic campaign of resistance mounted by Brazilian industrialists to topple the 1927 Minor's Code and recounts how, despite this opposition, Mello Mattos tried to fine industrialists from the cotton industry for violating the law (ILO, 1929-1930: 24). Paulista industrialists were furious about the minimum age provisions, the reduced daily working hours and the compulsory medical examination for the working child. They frequently denounced the Code in the press, while Mello Mattos defended it. Confidential internal correspondence from the industrialists' associations shows that they were angered by Mello Mattos' attempts to fine factories who violated the law - proof that he tried to enforce the 1927 Code's child labour provisions. Industrialists refused to pay fines and co-opted workers against the alleged financial and moral damage caused by the Minor's Code. The main industrial associations of Rio and São Paulo (CIFT/SP) and the Industrial Centre for Spinning and Weaving of Algodão in Rio (CIFTA/RJ) sent a petition to the National Congress asking for revision of the law. When Mello Mattos rejected the petition, CIFTA/RJ challenged his refusal before the Supreme Court. They argued that the Code damaged the national industry and that factory work was physically and morally beneficial for children and hence contributed to the preservation of the race (Braga, 1993: 138-147).

In 1929, the Brazilian Judiciary sided with the textile manufacturer Bonfim against Mello Mattos. Mattos' assistant had launched a disciplinary action against the factory manager for allowing approximately 150 children to work more than 6 hours daily. In their defence, the factory argued that the tasks were light and that the children did not work continuously, but took ample breaks in-between. The Supreme Court undermined efforts to enforce the Minor's Code by ruling: 'it has been shown that the kind of work is light, done with machines adjusted to the age, not surpassing 6 hours per day [...]' (Appeal no. 14, December 1929 in Braga, 1993: 150-153).

In 1931, a legislative Commission was formed to revise the factory child labour provisions of the Minor's Code, and in 1932, a revised federal decree was passed which extended children's working hours in textile factories to 8 hours per day; the adult ratio. While in the late 1910s, as we have seen, industrialists had succeeded in overturning a municipal child labour law from Rio via the Supreme Court, this was not entirely the case with the 1927 Minor's Code. The Minor's Code remained constitutional and lasted until 1979, when it was replaced, but an additional Decree was passed to dilute child labour regulations in factories, specifically. The minimum age provisions for all sectors including agriculture remained in place. However, it is likely that this legal defeat curbed subsequent officials' enthusiasm for enforcing the law - a subject that remains understudied.

\section{Concluding remarks}

Approaching child rights governance from a historical and comparative perspective, this article analysed how and why different systems of child governance - specifically child 
labour laws - emerged in the United States and Brazil. Overall, early child rights governance in Brazil and the United States differed significantly, and for several reasons.

In Brazil, the first major federal child rights law, the Minor's Code of 1927, covered a whole package of child welfare regulations ranging from child health, schooling and juvenile courts to child labour. In the United States, by contrast, the first federal child labour legislation of 1938, the FLSA, regulated child labour exclusively, while other child rights like schooling remained subject to state authority. Early child rights governance in the United States was strongly characterised by the federalist system; most child rights legislation was decided and implemented at state level. Early federal child rights legislation was further undermined by the traditional common law system which conferred significant power on local and state courts. These two defining features - the federalist system and the common law tradition - help explain why, in the United States, federal child labour legislation was late (1938), restricted in scope (covering industrial child labour only), limited in effect (industrial child labour declined from 1910 onwards) and comprised only a subsection of a law regulating adult labour. The FLSA was essentially an adult labour law containing a few child labour provisions, in contrast to the Brazilian Minor's Code which exclusively targeted children and constituted a comprehensive child rights law including a whole chapter on child labour.

As Brazilian reformers faced comparatively little political and juridical resistance, federal child labour regulation could be passed much earlier (1927) and was broader in scope (including agriculture). The expected lack of enforcement also explains why resistance to a federal child labour law was initially unimportant in Brazil. As early municipal or state-level child labour legislation was absent or ineffective, manufacturers likewise expected the Minor's Code to remain unenforced. Only when Mello Mattos enforced the federal child labour provisions, did they campaign for factory child labour regulations to be revised.

While conventional wisdom holds that the more extensively studied states of the Global North were more advanced in terms of child rights governance, including child labour regulations, this article has argued for more nuanced and even contrary assessments. The United States had a later, much weaker and less comprehensive national law, but state-level child labour legislation was sometimes stricter, enforced more rigorously and working families successfully used local courts to sue negligent employers (Schmidt, 2010). Whereas Brazil had an earlier, more comprehensive and more socio-politically progressive national child rights law, the limited enforcement of its child labour provisions and their eventual revision made them almost toothless. The case study shows that early child rights governance systems were conditioned and constrained by different types of federalist constitutions and judicial traditions which help explain the divergences in timing, scope, clustering and effect of early child rights legislation.

\section{Declaration of Conflicting Interests}

The author(s) declared no potential conflicts of interest with respect to the research, authorship, and/or publication of this article.

\section{Funding}

The author(s) disclosed receipt of the following financial support for the research, authorship, and/or publication of thisarticle: This piece of research was kindly supported by the Global South Studies Center (GSSC) at the University of Cologne. 


\section{ORCID iD}

Nina Schneider (iD https://orcid.org/0000-0003-0836-5664

\section{Notes}

1. For a discussion of the contested term "Global South", see Schneider (2018).

2. Among the wealth of national histories of child labour, for the British case see Humphries (2011) and Cunningham (1991), and for the United States, Hindman (2002) and Zelizer (1985). Some texts offer shorter national child labour histories of the South, for example, Hindman (2009) and Lieten and Meerkerk (2011).

3. Although the term "child labour" has been criticised for negative connotations, I retain it because this term was used at the turn of the twentieth century. Child labour here is broadly defined as a service that can be sold for money and harms the child's interests (at least in the long-run). Children are regarded as persons younger than eighteen.

4. It may be claimed that closing this minor gap was still significant in ending states' 'race to the bottom' in child labour standards.

5. While Milanich refers to England and France, it must be recognised that the illegitimacy rate varied greatly in Europe during the nineteenth century (see for example, Edvinsson, Brändström and Rogers, 2002: 29, 33, 39, 51). Overall, illegitimacy rates were higher in Latin American than in Europe.

6. For a general history of the Brazilian feminist movement between 1914 and 1940 see Besse (1996: 9, 89-109).

7. All translations have been made by the author.

8. This helps to explain why much of the secondary literature incorrectly claims that the Code set the minimum age at fourteen (e.g., Pieris 2004: 31; Kassouf and Santos 2011: 428).

\section{References}

Araujo RMB (1993) A vocação do prazer: a cidade e a família no Rio de Janeiro republicano. Rio de Janeiro: Rocco.

Alcindo Guanabara, Pela infancia abandonada e delinquent no Distrito Federal: Exposição de motivos e projecto de lei; apresentado ao Senado Federal na sessão de 21 de Agosto de 1917 (Rio: Typ. Do Jornal do Commercio, 1917).

Bandera V (2014) Práticas, leis e discursos modernizadores: o processo de construção do Código de Menores de 1927. Revista Eletrônica Direito e Politica 9(2): 736-754.

Besse SK (1996) Restructuring Patriarchy: The Modernization of Gender Inequality in Brazil, 1914-1940. Chapel Hill, NC: University of North Carolina.

BRASIL. Câmara dos Deputados. Sessão de 17 de julho de 1912. Projeto n. 94, de João Chaves.

Luigi B (2011) Classe e nação: trabalhadores socialistas italianos em São Paulo, 1890-1920. Campinas: Unicamp.

Braga AB (1993) A construção da infancia trabalhadora na la República. Master's thesis, Federal University of Rio de Janeiro (UFRJ), Rio de Janeiro.

Cunningham H (2005 [1995]) Children and Childhood in Western Society Since 1500. London: Pearson Longman.

De Carvalho JM (1991) Os bestializados: O Rio de Janeiro e a República que não foi. Rio de Janeiro: Companhia das Letras.

Dourado ACD and Hecht T (2004) Brazil. In: Fass PS (ed.) Encyclopedia of Children and Childhood: In History and Society. New York: Macmillan, pp. 114-117.

Edvinsson S, Brändström A and Rogers J (2002) Illegitimacy, infant feeding practices and infant survival in Sweden 1750-1950: A regional analysis. Hygiea Internationalis: An Interdisciplinary Journal for the History of Public Health 3(1): 13-52. 
Felt JP (1970) The child labor provisions of the Fair Labor Standards Act. Labor History 11: 474-475.

Gomes, Angela M. de Castro, Burguesia e Trabalho: Política e Legislação Social no Brasil 1919-1937 (Rio: Campus, 1979).

Guy DJ (2002) The state, the family, and the marginal child in Latin America. In: Hecht T (ed.) Minor Omissions: Children in Latin American History and Society. Madison, WI: University of Wisconsin Press, pp. 139-164.

Heywood C (2017) A History of Childhood: Children and Childhood in the West from Medieval to Modern Times. Cambridge; Medford, MA: Polity Press.

Hindman H (2006) Unfinished business: The persistence of child labor in the US. Employee Responsibilities and Rights Journal 18: 125-31.

Hindman H (ed.) (2009) The World of Child Labor: An Historical and Regional Survey. Armonk, NY; London: M. E. Sharpe.

Hindman H (2002) Child Labor: An American History. Armonk, NY; London: M. E. Sharpe.

Hobbs S, McKechnie J and Lavalette M (1999) Child Labor: A World History Companion. Santa Barbara, CA; Denver, CO; Oxford: ABC CLIO.

International Labour Office (ILO) (2002) Annotated Bibliography on Child Labour. Geneva: International Labour Office (ILO); International Programme on the Elimination of Child Labor (IPEC).

Kassouf AL and Dos Santos MJ (2011) Child labour in Brazil: More than 500 years of national shame. In: Lieten K and Van Nederveen Meerkerk E (eds) Child Labour's Global Past. Bern: Peter Lang, pp. 417-433.

Kuznesof EA (2009) History of childhood and child labor in Latin America. In: Hindman H (ed.) The World of Child Labor: An Historical and Regional Survey. Armonk, NY; London: M. E. Sharpe, pp. 317-320.

Lieten K and Van Nederveen Meerkerk E (eds) (2011) Child Labour's Global Past, 1650-2000. Bern: Peter Lang.

Luna FV and Klein HS (2014) The Economic and Social History of Brazil Since 1889. Cambridge, MA: Cambridge University Press.

Milanich N (2002) Historical perspectives on illegitimacy and illegitimates in Latin America. In: Hecht T (ed.) Minor Omissions: Children in Latin American History and Society. Madison, WI: University of Wisconsin Press, pp. 72-101.

Pieris P (2004) The United States. In: Schmitz CL, Traver EK and Larson D (eds) Child Labour a Global View. Westport, CT: Greenwood Press, pp. 185-198.

Rizzini I (2009) Crianças e menores - do pátrio poder ao pátrio dever: um histórico da legislação e da assistência à infância no Brasil. In: Rizzini I and Pilotti $\mathrm{F}$ (eds) A arte de governor crianças: A história das políticas sociais, da legislação e da assistência à infância no Brasil. São Paulo: Cortez, pp. 97-149.

Rizzini I (2011 [2007]) O Século Perdido: Raizes Históricas das Politicas para a Infância no Brasil. São Paulo: Cortez.

Rizzini I and Pilotti F (eds) (2011) A arte de governor crianças: A história das políticas sociais, da legislação e da assistência à infância no Brasil. São Paulo: Cortez.

Sandin B (2014) The history of children's well-being in the West. In: Ben-Arieh A, Casas F, Frones I, et al. (eds) Handbook of Child Well-Being: Theories, Methods, and Policies in Global Perspective. Dordrecht: Springer, pp. 31-86.

Schmidt JD (2010) Industrial Violence and the Legal Origins of Child Labor. New York: Cambridge University Press.

Schneider N (2018) Between promise and skepticism: The 'Global South' and our role as engaged intellectuals. The Global South 11(2): 18-38. 
Sklar KK (1995) Florence Kelley and the Nation's Work: The Rise of Women's Political Culture, 1830. New Haven, CT: Yale University Press.

Sklar KK, Schüler A and Strasser S (1998) Social Justice Feminists in the United States and Germany: A Dialogue in Documents, 1885-1933. Ithaca, NY: Cornell University Press.

Soares AM (2017) 'Precisa-se de um pequeno': o trabalho no pós-abolição no Rio de Janeiro, 1888-1927. Master's thesis, Federal University of the State of Rio de Janeiro (Unirio), Rio de Janeiro.

Stearns PN (2009) Child labor in industrial revolution. In: Hindman H (ed.) The World of Child Labor: An Historical and Regional Survey. Armonk, NY; London: M. E. Sharpe, pp. 38-43.

Stearns PN (2016) Childhood in World History. New York: Routledge.

Trattner WI (1970) Crusade for the Children: A History of the National Child Labor Committee and Child Labor Reform in America. Chicago, IL: Quadrangle.

Werner M and Zimmermann B (2002) Vergleich, Transfer, Verflechtung: Der Ansatz der Histoire croisée und die Herausforderung des Transnationalen. Geschichte Und Gesellschaft 28: 607-636.

Zelizer V (1985) Pricing the Priceless Child: The Changing Social Value of Children. New York: Basic Books.

Zinn H (1995) A People's History of the United States: 1492-Present. New York: HarperCollins.

\section{Manuscripts and Printed Primary Sources}

Arquivo Estadual de São Paulo [State Archive of São Paulo; AESP] (1894) Relatórios do ano 1894. São Paulo: State Archive of São Paulo (ASEP).

Barbosa R (1919) A questão social e política no Brasil. Rio de Janeiro: Fundação Casa de Rui Barbosa (Casa Barbosa Archive, hereafter: CBA).

Brasil Câmara dos Deputados (1906) Sr. Alcindo Guanabara vem sujeitar à consideração da Câmara um projeto de lei regulando a situação da infância moralmente abandonada e delinquent, session of 31 October 1906.

De Moraes E (1916) Criminalidade da infancia e da adolescencia. Rio de Janeiro: Francisco Alves.

Kelley F (1905) Some Ethical Gains through Legislation. New York: Macmillan.

Kelley F (1986) The Autobiography of Florence Kelley: Notes of Sixty Years (ed. KK Sklar). Chicago, IL: Charles H. Kerr.

ILO (1929-1930) Series young workers. Monthly reports by the Brazilian Representative M. de Souza. Geneva: ILO Archives, June-February.

Maria R. B. Alvim, 'Constituição da Família e Trabalho Industrial: Um Estudo de Caso sobre trabalhadores têxteus numa fábrica com Vila Operária', PHD Thesis, UFRJ, 1985.

Mello Mattos JC (1929) 'Prefacio'. In: BS Mineiro (ed.) Codigo dos Menores dos Estados Unidos do Brasil commentado. Rio de Janeiro: Imprensa Nacional (Proedes Archives, UFRJ, Rio de Janeiro, Urca; hereafter: Proedes), pp. iii-ix.

Mineiro BS (1929) Codigo dos Menores dos Estados Unidos do Brasil Commentado. Rio de Janeiro: Imprensa Nacional (Proedes).

Moncorvo Filho A (1926) Historico da Protecção á infancia no Brasil 1500-1922. Rio de Janeiro: Paulo, Pongetti \& Cia.

Presidência da República (1927) Decreto No 17.943-A De 12 De Outubro De 1927 (Minor's Code). Available at: http://legislacao.planalto.gov.br/legisla/legislacao.nsf/Viw_Identificacao/dec\%20 17.943-a-1927? OpenDocument (accessed 10 March 2018).

U.S. Department of Labor (2011 [1938]) The federal standard labor act of 1938, as amended. Available at: https://www.dol.gov/whd/regs/statutes/fairlaborstandact.pdf (accessed November 10, 2017) 


\section{DuEPublico}

Duisburg-Essen Publications online
UNIVERSITÄT

$D_{E} U_{S} I_{S} B_{N} B_{N} R$

offen im Denken

$\mathbf{U b} \mid \begin{gathered}\text { universitäts } \\ \text { bibliothek }\end{gathered}$

This text is made available via DuEPublico, the institutional repository of the University of Duisburg-Essen. This version may eventually differ from another version distributed by a commercial publisher.

DOI: $\quad 10.1177 / 0907568219850241$

URN: urn:nbn:de:hbz:464-20210506-111236-0

This publication is with permission of the rights owner freely accessible due to an Alliance licence and a national licence (funded by the DFG, German Research Foundation) respectively.

(C) The Author(s) 2019. All rights reserved. 